\title{
Mobile-Assisted Language Learning (MALL) in Indonesian Islamic Higher Education
}

\author{
Rully Agung Yudhiantara \\ UIN Sunan Gunung Djati Bandung, Indonesia \\ E-mail: rully.agung@uinsgd.ac.id \\ Andang Saehu \\ UIN Sunan Gunung Djati Bandung, Indonesia \\ E-mail: andangsaehu@uinsgd.ac.id
}

\begin{abstract}
:
Mobile phone use has been studied in its connection with foreign language learning by many researchers concerned in Mobile Assisted language learning (MALL) for more than a decade. In Indonesian Islamic higher education context, the issues of MALL has not been discussed extensively. To respond to this need, this study was aimed at investigating the following research question: 1) How do students use their mobile phone to learn English Monolingual Dictionary (EMD) application?; 2)How do students use their mobile phone to support English language learning?. This study employed qualitative method using case study. To collect data, this study applied observation to find out students' engagement in using mobile phone for learning EMD application. Students participated in this study were 40 students. Findings showed that students were able to use mobile phone to use EMD application in English language learning (ELL). They demonstrated skill in operating EMD application which was realized in their knowledge concerning, pronunciation, grammar and meaning information when searching a particular word. In addition there were many features that students seized from mobile phone for English language learning. They used audio feature to operate EMD from mobile phone to boost listening skill. Their mobile phone facilitated them to record video project presenting their vocabulary learning. These activities could be done
\end{abstract}


by their mobile phone existence as an introductory effort toward MALL implementation in ELL in Islamic Higher education.

Keywords: English Language learning (ELL), English Monolingual Dictionary (EMD), Mobile Assisted language Learning (MALL), Mobile phone

\section{Introduction}

ICT and education are closely related. ICT has contributed to education in many aspects. ICT has assisted teachers and learners in teaching and learning activities in order to achieve obejctives of education (Kee \& Samsudin, 2014; Laabidi, 2016; Laabidi \& Laabidi, 2016; Khaloufi \& Laabidi, 2017; Chouit, et al., 2017). There are many forms of ICT that are open to be explored and applied in education. One of the emerging technology which joins the line up to assist education is mobile phone. Mobile phone has fulfilled not only its basic purposes that is communication purpose but also aid for educational purpose. It offers features and capacity that are open to be explored for educational purposes. It takes creativity and effort on the part of teacher and students to use mobile phone for supporting language learning (Newhouse, William \& Pearson 2006).

To seize mobile phone benefits, School and universities can promote the use of mobile phone to support their student in learning foreign language. This effort is in line with the fact that teenagers and youth always carry their mobile phone and spend their life screening mobilephone (Prensky 2001). The term digital natives was coined to mark this generation characteristics in that they live with their gadget which is supported by internet connection. In other words youths are inseparable from their gadgets.

Mobile phone has started to gain popularity and competed with personal computer to meet users' need. The companies have developed mobile phone to adopt and perform the way personal computer do. The rise of Mobile phone in digital natives life is taking place. In response to this promising mobile phone development, language teachers and researchers have responded by promoting mobile phone for language learning. The term mobile Assisted language learning (MALL) has come into existence. Like Computer Assisted Language learning (CALL) which benefited from computer for language learning, MALL promotes the promising benefit of mobile phone to support language learning.

MALL according to researchers has been associated with some characteristics. One of MALL characteristics is the notion of mobility. This notion provides language learner brand new learning experience where language learning can take place anywhere. Some studies reported the benefit of mobility for language learning. This characteristic offers many benefits for language learners and it can be implemented in higher education (Sharples et al. 2009). Another study found that mobile phone offered students benefit in assisting them learn, especially learning English language, in higher education level (Zeng \& Luyegu 2011). In ther words, MALL 
responds to the contextual need of teenagers and youth because it offers innovation in learning language (Kukulska-Hulme et al. 2009).

In Indonesian Islamic Higher education context (IHE), MALL has not gained enough attention and the studies concerning MALL have not been published in a number of articles of national journal. This study tried to fill in the gap of MALL research in Indonesian context. It investigated MALL introduction in Indonesian IHE that offers English subjcet in its curriculum. It specifically focused on learning how to operate EMD applicaton that students intalled and operated throught their mobile phone. In addition this study investigated students' experience to use mobile phone in order to support their ELL.

Based on the above background, this study formulated the following specific research questions:

(1) How do students use their mobile phone to learn English Monolingual Dictionary (EMD) application?

(2) How do student use their mobile phone to support English language learning (ELL?

\section{Literature Review}

In general this section discusses MALL including its brief introduction, its characteristics in ELL, its implementation. Other issues concerning several studies reporting MALL, its benefit are also discussed.

\subsection{Mobile Assisted Language Learning (MALL)}

Mobile phone has brought many opportunities for foreign language teachers to assist their teaching activities. In language teaching and learning, the term MALL has developed as a branch from its predecessor that is Computer Assisted language learning (CALL). In Korean higher education, a study has reported that MALL promoted the so-called ubiquitous learning. They found that mobile phone encouraged students to learn anywhere and anytime as long as they carried mobile phone. Their mobile phone was used to access material for learning (Lee, Lee \& Kweon 2013).

In the context of ELL, there were studies concerning MALL that supported student to learn component and skills of foreign language. Teaching and learning vocabulary have benefited much from mobile phone existence that supported language learners. Reading skill has also gained advantage when students used their mobile phone to support their learning process (Plester, Wood \& Joshi 2009).

Mobile phone with all its feature are open to be explored to allign with the need of langauge learning. Bull (2004) found that camera feature in mobile phone assisted learning process. This feature of camera was taken into consideration when designing the curriculum to benefit from camerea feature for learning process (Bull \& Thompson 2004). Smythe (2010) found that audio video feature helped students create podcast that were beneficial in learning process. The use of mobile phone to 
play podcast was crucial since it helped students create learning community among English language learners (Smythe \& Neufeld 2010). In addition video recording has been proven to serve as digital learning tools among students in learning language. This feature was proven to be helpful device in improving students' language skills (Gromik 2012).

In foreign language class, students who are digital natives are the main actors and they should be taken into consideration when promoting MALL. Compared to their teachers who belong to digital immigrants, students are familiar with gadget and all its feature that they use daily to meet their need (Prensky 2001). A study reported students' perception concerning integration of mobile phone into classroom activities. Students had positive perception on mobile phone integration for classroom activities (Thomas \& Munoz 2016). Other study conducted by Al-Fahd (2009) found that student were ready to integrate their mobile phone for English language learning activities. They exhibited positive attitude and perception on inegration of mobile phone for classroom activities. In other words sudents are more likely to integrate mobile phone for classroom activities (Al-Fahd 2009).

On the part of students, they gain benefit by using mobile phone for English learning activities because they were given opportunities to regulate and maintain their progress in ELL (Sha, Looi, Chen, \& Zhang, 2012). This advantages provide additional value for language learners to organize their ELL at their own pace. In a nutshell mobile phone is promising educational tool that might help students to regulate their ELL on their own learning pace.

On the other hand, students can conduct collaboration with their classmates. The need to collaborate between students and teacher and among students can be facilitated by mobile phone since there are many applications which cater students need for collaboration (Corbeil \& Valdes Corbeil 2007). Those application include social media that are popular among users like facebook, twitter, Whatssapp. Those application are powerful application for collaboration purpose in supporting english language teaching and learning process.

Responding to this trend, teachers should learn more and spend their time to explore mobile phone potential in assisting their teaching activities. It takes more creativity and in depth consideration for teachers to introduce MALL in their classroom. a study reported that mobile phone along with its supporting features has allowed language teachers to personalize their instruction activity in their classroom (Steel 2012). It is the teachers with their creativity that makes possible for personalizing instruction to achieve objective of instruction.

Mobile phone has many applications that facilitate interaction among users. Teacher and students may increase their interactivity and maintain their communication using applications available in their mobile phone. A study reported that mobile phone featuring messaging service were helpful to maintain interaction between teachers and learners. Markett (2006) studied interaction between teachers and students for teaching and learning purposes. The increase and improvement of 
communication and interaction were supported by their mobile phone featuring messaging service existence and assistance (Markett et al. 2006).

There are many benefits that teacher can gain by using mobile phone for teaching and learning activities in school. Liu (2015) found that MALL enabled teacher to provide differentiated learning pathways for students. Teachers also offered multiple modality for students to produce their portfolio, support students improvisation and learning creation (Liu et al. 2015). In a larger scale for mobile phone integration in schools, Pegrum (2013) found that students were ready to join and accomplish task by using mobilephone for classroom related work. The study reported that students were able to cope with the task and classroom activities by using their mobile phone (Pegrum, Oakley, \& Faulkner, 2013).

\subsection{Previous Research}

Khabiri (2013) reported Mobile phone use practices among Iranian EFL Learners in university level. The study found that mobile phone offered many promising features which were open to explore by the teachers for delivering English language learning to university students (Khabiri \& Khatibi 2013 ).

Kee and Samsudin (2014) conducted research on mobile phone use for educational activities for teenagers in school in Malaysia. The findings showed that student had positive perception and attitude toward mobile phone use for learning language anytime and anywhere. Students viewed that mobile phone offered mobility that enabled them to access material for learning anywhere and anytime (Kee \& Samsudin 2014).

In Nigeria a study conducted by Oyewusi (2014) concerning mobile phone use to promote reading habit. The study suggested that mobile phone should be designed in an appropriate way with supporting application to promote reading habit among language learners (Oyewusi \& Ayanlola, 2014).

Since there is a little literature reporting MALL implementation in Indonesian islamic higher education, this study tried to fill in the gap.

\section{Research Methodology}

This study was aimed at investigating how students use their mobile phone to operate EMD. In addition it also explored how students use mobile phone to support ELL. To achieve the objective of the study, this study applied case study. The study involved 40 participants: 30 female students and 10 male students. Participants in this study were students of Islamic Religion education, Tarbiyah Faculty who took English 2 subject.

Observation was applied in this study to collect data concerning students' engagement in using mobile phone to operate EMD and to support their ELL activities. Interviews was also deployed to gain more data from students. The data collected in this study were analysed qualitatively to answer research questions in this study. They were described and categorized in order to meet the need of research questions. Interpretation to data was applied in order to comprehend the 
findings and the literature review. Triangulation was applied to enhance the validity of the findings in this study.

\section{Findings}

This study was aimed at investigating students' engagement in using mobile phone to operate EMD and to support ELL. The data collected in this study consisted of two types, first students experience in using mobile phone to operate EMD application and second, Students' experience in using mobile phone to support ELL activities.

\subsection{Operating EMD application in Mobile Phone}

Prior to data collection, the teacher in the beginning semester informed students concerning MALL and EMD application that would be integrated in their classroom. Students showed their readiness to use their mobile phone in operating mobile phone to lear EMD application. This application was not familiar among students in this study since no student had installed EMD in his/her mobile phone. This study found students were not familiar with EMD application and they preferred to have bilingual dictionary English-Indonesia in their mobile phone.

In contrast to EMD, bilingual dictionary was popular among students. More than half students had bilingual dictionary application in their gadget. Bilingual dictionary helped them to access meaning and information concerning English word they found during reading text. They gained benefit from this bilingual dictionary in terms of ease of use, instant and swift assistance to understand definition and meaning of a particuar English word in its Indonesian equivalent. Some students expressed and supported this notion as can be seen in the following excerpt:

" $i$ really need English indonesia dictionary, it helps me understand meaning of a particular English word in Indonesia"

This study found that EMD application was not found in students' mobile phone. This condition occured because of some reasons. EMD application was not familiar compared with bilingual dictionary. It is widely known that language learners usually need bilingual dictionary when learning foreign language. Students had no ample knowledge concerning EMD application for their ELL activities. Neither knowledge nor experience that students in this study possessed. Their opinion can be seen in the excerpt as follows:

"I dont know EMD in my previous school experience and $i$ did not have any experience to use EMD in school in the past)

In the same vein a student expressed his opinion as follows:

"It's difficult to use EMD when learning English because the explanation is delivered in English"

The above statements describe in general what students had in their mind concerning the role of dictionary and difficulties to operate EMD application compared to bilingual dictionary. 
In the following meeting, students learned EMD application from the teacher. For students, it took shorter time to get to know EMD application after they installed it in their gadget. They found no difficulty to access EMD and operate several options available in EMD application. It goes without saying that those students belonged to digital native who were familiar with gadget and all the application they operated in theirs. This is in line with statement from a student in this study as he expressed her comment as follows

\section{"Installing and operating EMD application are not difficult sir"}

EMD application has several basic features that students had to learn in order to gain the benefit that the EMD application offers to student in ELL activities. First feature deals with pronunciation application. This feature comes first in EMD application and it is placed at the top initiating information delivery about a particular word. Pronounciation information delivers audio that students listened to when dealing with how to correctly pronuounce a particular word. This feature was considered very beneficial for student since they were in trouble to make sure how should a particular word be pronounced. This was the benefit that students found when they operated this pronunciation information. A student expressed her opinion as follows:

"This feature of pronunciation is good, $i$ can use it to learn to pronounce correctly the word"

Another feature that EMD offers is Grammar information concerning a particular word. This information is delivered in EMD application after pronunciation information. It has something to do with concepts of parts of speech of a particular word. In thi study, students found that grammar information helped them to know what parts of speech that a particular word possiby have. This is what student expressed in the following statement:

\section{"EMD application is very helpful, I can find out frammar information} of a particular word)

The third feature perhaps is the most challenging part that EMD offer for users in this study. Student had to deal with information delivered in English language concerning a particular word. Students in many occasion face difficulties and struggled to understand explanation delivered by EMD concerning a particular word. A following statement was expresed by a student:

"it is difficult sir, since the explanation is delivered in English, I have to think and try to understand the information of a particular word"

Having learned how to operate EMD application, students were given task requiring their mobile phone use to deal with EMD application. In reading subject, students encountered many words that they were not familiar and they did not know their meaning. The teacher encouraged their student to use EMD application from their mobile phone to solve their problem in searching approriate meaning of a particular vocabulary. 
The more they practiced using their mobile phone to acces EMD application, the more they were skilfull to access meaning and understand a vocabulary. Students opinion concerning EMD application shifted from negative to positive perception. In the beginning course students perceived EMD application was difficult to operate for ELL activities. In the end of the course students had positive perception toward EMD application. This is what the student expressed in the following statement:

"in the beginning, it was difficult to operate EMD and learned from this application, now i like to operate it because it offers many advantages)

\subsection{Using Mobile Phone to Support ELL Activities}

In this section, the findings concerning mobile phone features that helped student in ELL activities will be displayed. The teacher provided reading material that can be stored in their mobile phone. Students operated their mobile phone to read reading material in the classroom. the teacher encouraged students to read English reading material outside classroom.

Students in each meeting operated their mobile phone to read material in form of PDF. They found mobile phone helpful to facilitate them learning English. This opinion was expressed by a student as follows:

"it is more convenient for me, mobile phone can be used to read the material"

Other feature that helped student in ELL activities was audio video player. Students were given video and podcast concerning particular topic relevant to the topic they read in English subject. It goes without saying that They learned listening skill from this feature by playing podcast operated in their mobile phone. A student expressed her opinion as follows:

"watching video from mobie phone is easier, $i$ can go anywhere and learn anywhere by accessing the vieo fro mobile phone"

Student mobile phone offered video recorder feature that they used to produce project. This study found that students were able to create short video that featured their speaking skill by presenting a particular topic in short video. This project was created to fulfill the assignment gien by the teacher. Their mobile phone facilitated them to produce a video showing their ELL activities. a student commented as follows:

"it is awesome, our mobile phone has video recorder feature. We can use our mpbile phone to create video project"

\section{Discussion}

This study found that each student had their mobile phone that they carried to campus. It goes without saying that mobile phone ownership among youth is high. This is in line with the previous findings that students in higher education are incresingly using mobile phone to access internet (Kennedy 2014). Many mass media reported the successful sale of mobile phone in Indonesia. It can be concluded that youth customer is the largest customer of mobile phone. The findings in this 
study confirmed the previous research by Lenhart (2015) that teens and youth are the largest customer of mobile phone and they have used their mobile phone to go online for their pleasure and need. In other words, teen and gadget are inseparable (Lenhart 2015).

Some applications had been instaled in students' mobile phone to support ELL activities. They had installed offline dictionary. This apps was the most frequently installed apps in students' mobile phone that they usually use to support learning. It goes without saying that mobile phone has promoted ELL activities (Nisbet \& Austin 2013). Other apps they use is PDF Reader for operating e-book. This apps was useful app for students to read e-book another reading material. This findings confirmed previous studies that features in mobile phone help students learn reading and vocabulary (Plester, Wood \& Joshi 2009). In other words mobile phone when used approriately may build reading habit among students (Oyewusi \& Ayanlola 2014).

From observation, students seemed to enjoy the ease and portability of mobile phone that helped them learn in classsroom. They found it more practical to use mobile phone compared to notebook in classroom activites (Lenhart 2015). In a nutshell Mobile phone served as a learning tool in the 21 st century (Kee \& Samsudin, 2014). In classroom students used their mobile phone to play audio video material. Without difficulties, students could access and played their file in their mobile phone. According to their opinion, it was clear that feature of audio video player in their mobile phone helped them in learning proces as the previous research had proven (Smythe \& Neufeld 2010). Mobile phone can be used to gain its benefit in ELL activities in Indonesian IHE (Yudhiantara \& Nasir 2017 ).

\section{Conclusions}

This study discussed MALL which is the promising educational technology in conducting mobile learning for educational purposes. This study is important in the context of Islamic higher education in Indonesia for implementing MALL to support ELL. To date, the issue of MALL has not been studied exensively in Indonesian Islamic Higher Education. This study might initiates the development of MALL to support ELL activities in Indonesian IHE.

This study found that students engaged in using mobile phone for learning EMD application. They were able to operate and access all feature of EMD application to support ELL activities. Other findings related to several activities that students performed in reaping benefit of mobile phone for ELL activities. The activities included: Reading pdf file, playing audio file from their mobile phone, creating video project were the examples. This study offers some brand new approach in ELL activities by the existence and assistance offered by mobile phone. MALL offers promising way to support ELL activities in Indonesian Islamic Higher Education. 


\section{References}

Al-Fahd, F. (2009). 'Students' Attitude and Perception Toward the Effectiveness of Mobile Learning in King Saud University, Saudi Arabia', The Turkish Online Journal of Educational Technology (8) 2, pp. 111-119.

Bull, G \& Thompson, A. (2004). 'Establishing Framework for Digital Images in the School Curriculum', Leading and Learning with Technology (31) 8, pp. 14-17.

Chouit, D., Nfissi, A., Laabidi, H. (2017). Exploring the Correlation between Professors' Use of ICT in Teaching and the Levels of Institutional Support. JELTL (Journal of English Language Teaching and Linguistics), 2(1), 2017. doi: http://dx.doi.org/10.21462/jeltl.v2i1.39

Corbeil, JR \& Valdes Corbeil, ME (2007) 'Are You Ready for Mobile Learning?', EDUCAUSE Quarterly (30) 2, pp. 51-58.

Gromik, NA. (2012). 'Cell Phone Video Recording Feature as a Language learning Tool: A Case Study', Computer \& Education, pp. 223-230.

Kee, CL \& Samsudin, Z. (2014). 'Mobile Devices: Toys or Learning Tools for the 21st Century Teenagers?', TOJET: The Turkish Online Journal of Educational Technology (13) 3, pp. 107-122.

Kennedy, DM. (2014). 'M-Learning to Suort Learning English in Hongkong University', MERLOT Journal of Online Learning and Teaching (10) 4, pp. 640-655.

Khabiri, M \& Khatibi, MB. (2013). 'Mobile-Assisted Language Learning: Practices Among Iranian EFL Learners', European Online Journal of Natural and Social Science (2) 2, pp. 176-190.

Khaloufi, Az-eddine \& Laabidi, Hicham. (2017). An Examination of the Impact of Computer Skills on the Effective Use of ICT in the Classroom. Indonesian Journal of EFL and Linguistics, 2(1), 2017

Kukulska-Hulme, A, Sharples, M, Milrad, M, Arnedillo-Sanchez, I \& Vavoula, G. (2009). 'Inovation in Mobile Learning: A European Perspective ', International Journal of Mobile and Blended Learning (1) 1, pp. 13-35.

Laabidi, Hicham. (2016). The Effect of Age on English Professors' Integration of the New Technologies in Teaching. IJELTAL (Indonesian Journal of English Language Teaching and Applied Linguistics), 1(1), 2016

Laabidi, Youssouf \& Laabidi, Hicham. (2016). Barriers Affecting Successful Integration of ICT in Moroccan Universities. JELTL (Journal of English Language Teaching and Linguistics), 1(3), 2016

Lee, H, Lee, WB \& Kweon, SC. (2013). 'Conjoint Analysis for Mobile Devices for Ubiquitous Learning in Higher Educatio: The Korean Case', TOJET (12) 1.

Lenhart, A 2015, 'Teens, Social Media \& Technology Overview. (2015). Pew Research Centre's Interne \& American Life Project.

Liu, M, Scordio, R, Renata, G, Navarete, C, Yujung, K \& Lim, M. (2015). 'A Look at Research on Mobile Learning in K-12 Education from 2007 to the Present ', Journal of Research on Technology in Education (46) 4, pp. 325-372.

Markett, C, Sanchez, IA, Weber, S \& Tangey, B. (2006). 'Using Short Message Service to Encourage Interactivity in the Classroom', Computers and Education, pp. 280-293. 
Newhouse, CP, William, PJ \& Pearson, J. (2006). 'Supporting Mobile Education for re-service Teachers', Australasian Jounal of Educational Technology , pp. 289-311.

Nisbet, D \& Austin, D. (2013). 'Enhancing ESL Vocabulary Development Through the Use of Mobile Tehnology', Journal of Adult Education (42) 1, pp. 1-7.

Oyewusi, F \& Ayanlola, AO. (2014). 'Effect on Mobile Phone Use on Reading Habit of Private secondary School Student in Oyo State Nigeria', School Libraries Worldwide (20) 1, pp. 116-127.

Plester, B, Wood, C \& Joshi, P. (2009). 'Exploring the Relationship Between Children's Knowledge of Text Message Abbreviation and School Literacy Outcomes', British Journalof Developmental Psycholog (27) 1, pp. 145-161.

Prensky, M. (2001). 'Digital Natives, Digital Immigrants', On The Horizon (9) 5.

Sharples, M, Arnedillo-Sanchez, I, Milrad, M \& Vavoula, G. (2009) 'Mobie Learning: Small Devices, Big Issues', in Technology- Enhanced Learning Principles and Product, Springer-Verlag, Berlin, Germany.

Smythe, S \& Neufeld, P. (2010). 'Podcast Time. Negotiating Digital Literacies and Communities of Learning in a Middle Years ELL Classroom ', Journal of Adolescent \& Adult Literacy (53) 6, pp. 488-496.

Steel, C. (2012). 'Fitting Learning Into Life: Language Students' Perspectives on Benefits of Using Mobile Apps', in Future Challenges, Sustainable Futures, Wellington, New Zealand.

Thomas, K \& Munoz, MA. (2016). 'Hold the Phone! High School Students' Perception of Mobile Phone Integration in the Classroom ', American Secondary Education (44) 3, pp. 19-37.

Yudhiantara, RA \& Nasir, IA. (2017). 'Toward Mobile-Assisted Language Learning (MALL): Reaping Mobile Phone Benefits in Classroom Acivities', Register Journal (10) 1, pp. 12-28.

Zeng, R \& Luyegu, E. (2011). 'Mobile Learning in Higher Education', in Informed Design of Educational Technologies in Higher Education: Enhanced Learning and Teaching, Idea Group Inc (IGI), Herhsey, Philadelphia. 